\title{
Principals' Perceptions on the Notion of Organizational Culture: The Case of Greece
}

\author{
Theodora Tzianakopoulou ${ }^{1}$, Nikolaos Manesis ${ }^{2, *}$ \\ ${ }^{1}$ European University Cyprus, Cyprus \\ ${ }^{2}$ Department of Primary Education, University of Patras, Greece
}

Copyright $(\mathrm{C} 2018$ by authors, all rights reserved. Authors agree that this article remains permanently open access under the terms of the Creative Commons Attribution License 4.0 International License

\begin{abstract}
Organizational culture constitutes a fundamental characteristic of the educational organism, because, it contributes to the shape of its character and of its members' way of thinking and behavior and, it is also connected to the employees' productivity and the students' academic performance. It is commonly held that leadership and organizational culture are in a constant process of interaction and heteronomy, constituting two sides of the same coin. Therefore, one of the most important tasks that the educational leader undertakes is to create and manage organizational or school culture. We conducted research by subjecting a number of secondary school principals within Attica Prefecture in Greece to semiconductor interviews regarding the way in which they perceive the notion of organizational culture investigating the circumscription of culture, its contribution to the development of the school, its differentiation from the school climate, the principals' vision for the culture of their school. It is clearly evident by the results that the notion of organizational culture is neither perceived nor defined by everyone in the same way resulting in it being frequently identified with the Organization and Administration of the school unit, while confusion with the notion of school climate is also observed.
\end{abstract}

Keywords Organizational Culture, Principal, Secondary Education, Greece

\section{Introduction}

Organizational culture has been investigated in the education sector mainly in decentralized education systems.

Culture, a fundamental component of an organism and an indicator of its quality is a complex, multidimensional, multileveled, and widely investigated notion, and even though culture has been proved a critical aspect of schools, and a crucial component for creating change in schools, there is no standard definition of the notion [5 - 12]. It is interpreted as the symbols, rituals, and myths that convey the values and perceptions of the organism to the employees [13], as the ideology of the organism, containing its perceptions and customs which differentiate it from the other organisms [14], as a system of commonly held perceptions which distinguishes one organism from the next [15]. Therefore, culture functions as a means of comprehending of what happens within an organism, as a frame of defining the reality of the organism [16, 17], as "a common system of common orientation that keeps its members in check and assigns a special identity to it. The orientations are the values, rules, myths, behaviors, and silent acceptances" [18], according to which the organism functions and concern organizational culture.

Organizational culture is often confused with the climate of the organism [19], or with the terms school climate and school ethos [11], as both notions, culture and climate, focus on the way in which the members of the organism perceive their environment [20], and both notions constitute basic factors for the description and analysis of organizational phenomena [21], and both notions are based on the existence of fundamental acceptances regarding the function, but also the comprehension of its organizational structure [22].

More specifically, the special character of the school, which constitutes an organism [23], is shaped by the culture and the climate, a fact that caused the extensive investigation of both notions [24, 25]. As school culture affects school climate [26], for instance an organization's culture is a behavioral manifestation of its climate [27], the climate constitutes an element of organizational culture. By extension, many researchers perceive the two notions as identical or the climate as a subset [28, 29], an interpretation [30] or as a superficial expression of culture [31], even though the historical origins of the climate are traced to the science of psychology, while those of culture to anthropology and sociology [32]. Conclusively, culture comprises mainly of values and norms, has dimensions which are more generalized and holistic and is approached 
through qualitative investigation [29].

While climate descriptively ascribes what happens within an organism, culture attempts to define the cause of what happens $[10,33]$. More specifically, climate, the atmosphere of the school organism $(34,22,35]$, expresses how the employees perceive the organism on issues of practices, policies, processes, routine, and compensations $[36,37,20]$, focuses on the status quo depicting the employees' perceptions, feelings, and behavior and is considered ephemeral, subjective, and possibly dictated by the administration of the organism [38]. On the contrary, culture concerns fundamental ideologies [39] and acceptances [40], common values [18, 41], school administrators' basic tasks, such as setting goals and objectives for the school and education regarding the values desired to take place at school [42], "a positive atmosphere" [43]. It is influenced by the symbolic interpretations of what happens in an organism and by the behavioral norms [44], is more stable than climate, has strong roots in history, demands collectivity, and is resistant against actions which shape it $[38,40]$.

Organizational or school culture is constructed by all the stakeholders within the education organism namely educators, students, principals, parents, administrative and supportive staff $[45,46]$, who all have the expectation their psychosocial, developmental, and educational needs will be taken care of [47 - 49]. From this point of view, individual goals have to be converted to share goals in schools, indicating there is a collective consciousness among the members and the coherence of a shared vision developed by the headmaster. Thus, it is crucial the school leader make the shared vision compatible with the school culture [43]. When shared vision is combined with coherence in culture, it makes the vision more achievable, which allows school leaders and their employees to turn the vision into action [50]. Moreover, organizational or school culture focuses on the members' beliefs and values, which, in many cases, are not easily perceived [35], and also on common goals and learning objectives [51] or it is connected to respect to hierarchy and the structures of the organism [52]. So, school culture is not static, but dynamic, in direct relation to the human element, which, according to Tschannen-Moran [53], an efficient headmaster allows the school to manage its critical human resources more effectively, comprised of convictions, values, and beliefs that essentially hold the school organism together, ascribing to it a common identity and contributing to the shaping of its character [54]. More specifically, it concerns the behavioral tactics of employees [7, 55 - 61], norms which are developed within the frame of the individual groups, fundamental values of the organism, policy towards the clients and employees, rules of the survival game within the organism, the internal climate of the organism, and the way of interaction between the employees and the clients as well as among themselves [61].
Research concerning organizational culture emphasize that culture has a great role on effectiveness [62-64] and academic achievement [41, 62, 64-69], as effective leaders who create culture have an indirect but profound impact on school's effectiveness and students' achievement [70-72].

Furthermore, there are many studies revealing the relationship between school culture and job satisfaction [73-74], school culture and organizational commitment [69, 73-74].

Organizational culture has been interpreted in many ways [22]. Indicatively, Verbeke, Volgering \& Hessels [75] highlighted 54 different definitions in the bibliography between 1960 and 1993. Generally researchers seemingly perceive it shared among the members [76], constituting not only a group practice, but also a group action, the "practice of entities" [6], influencing the stances and behaviors of employees [64], comprising of common values, beliefs, and acceptances [10], existing on many levels, like collective or organizational [78], being perceived as a notion holistically by the researchers, among whom Schein as well $[29,79]$. Schein $[10,40,45]$ put forward the most popular and concise definition, which is also accepted in the present paper. "Organizational culture constitutes a standard of basic acceptances which are discovered or developed by a specific group when it learns how to deal with problems of outward adaptation and inward fulfillment, which has been sufficiently tested in order to be considered valid and for that reason to be taught to new members as the correct way of perception, thought, and sense regarding these problems."

According to Schein's holistic approach [15], the first level of culture (artifacts) is constituted by visible characteristics of the physical environment of the organism, but also behavioral norms conveyed to the members of the organism via stories and rituals and providing visible examples to the organism about the culture $[80,18]$.

The second level (espoused beliefs and values) includes a system of common values which, on one hand, is reflected on the goals of the organism and, on the other, it influences the members' behavior, who try to convert the values to behavioral norms of the first level.

Lastly, at the deepest and most abstract third level (underlying assumptions), in which the essence of culture is included [35], lie the unconscious, abstract convictions, perceptions, thoughts, and emotions of the members of the organism which are related to human nature, human relationships, truth, and the environment, comprising the primary source of values and action.

Conclusively, culture, extremely important for the survival and development of the organism, consists of apparent and obscure behavioral models which are acquired and transmitted through norms, values, philosophies, perceptions, and acceptances that contribute to its formation. It creates distinct boundaries among organisms, providing a sense of identity to the organism, eases the development of devotion within the group, 
increases stability within the social system, is responsible for the formation of the organism as well as its members' suitable behavior [81], enhances the energy, motivation and vitality of school community members [75], strengthens the organism, limit the cases of members' leaving the organism [82], and affects effectiveness [83]. It contributes to better communication among staff; students; and directors, and to the choice of more efficient solutions for problem solving and increases interest in the values and ethos of the school [98-99].

The general aim of the present paper is the investigation of the perceptions held by principals who work in secondary public schools within Attica Prefecture regarding the issue of organizational culture in education, on a theoretical and practical level.

The study of the notion within the frame of a centralized system, like the Greek one, within the headmaster, mainly, deals with the administrative operation of the school as an organization through bureaucratic procedures involving day-to-day routine and conductive administrative tasks [1], constituting indeed a challenge if headmasters may accept skeptically the central educational policy and shape along with all members of the school unit, its "internal" policy [2 - 4], gives rise to the comparative validation of the Greek educational reality in relation to the European or world facts. The location, in fact, of the conducting of the research, as well as the choice of the qualitative method contribute to the overcoming of the regional validity of the conclusions and to the obtainment of a realistic evaluation regarding the administration of the educational organism.

\section{Materials and Methods}

The question with which we have dealt with was: How principals perceive the notion of school culture?

The qualitative approach was selected whose aim is the in-depth approach and comprehension of numerous and different dimensions of human behavior, as they are defined by social processes, conditions, and meanings [84].

More specifically, the semiconductor interview was used as a tool for the collection of data regarding the investigation of secondary school principals' perceptions and practices, as it is flexible and suitable for the gathering of empirical data through the analysis of the interviewees' answers, allowing for clarifications to be offered and for other matters to be discussed which will possibly emerge throughout its duration [85-87].

The research was conducted between February and April 2017. The participants were the principals of all public secondary schools and more specifically of junior high schools and high schools who served in schools within Attica Prefecture secondary schools during the 2016-2017 school year. Prefecture of Attica is the representative of Greece, as the $34 \%$ of Junior High schools and $35.4 \%$ of High schools of the country operate there.
The research questions arose from both the study of literature and from the long experience of researchers in the field in positions of responsibility (directors, school counselor).

In order to increase the validity of the research ${ }^{1}$ even though it is a qualitative one, we used as way of sampling the sampling by layers. Attica Prefecture schools were recorded in numerical order, by administrative education zones, noting the type of school (High School - Lyceum) and the principals' gender. ${ }^{2}$ From a random number table [88] the schools were selected in a way according to which one of the two conditions to be different (gender or school type). In this way we finally selected an equal number of schools as far as Administration zone (1 from each Administration zone and 2 from the largest ones), school type, and the principals' gender were concerned. ${ }^{3}$ Twenty schools were initially selected. Communication with the principals which had initially been selected ensued, the necessary clarifications were provided, and the time and place for the carrying out of the interview were confirmed. In total, six of the principals who had initially been selected refused to participate for different reasons (mainly lack of time).

The sample finally consisted of ten principals, aiming for equal participation from both genders, based on the rule of adequacy, which is necessary for the carrying out of a quality research [89].

Before the interviews, we received 2 pilot in order to observe any problems or misunderstandings, and then we drafted the interview guide. In order to increase the validity of the research, we gave the transcripts to two participants who confirmed the accuracy of their reasons (participant validation) [91]

The adequacy for our research was achieved on the eighth interview, but two more interviews were conducted for the validity of the research to increase. All principals have been serving in education from 23 to 35 years. The years in service vary from 2 to 26. Two (2) possess Master's degrees and one (1) a $\mathrm{PhD}$ too. One of the principals has had further education on administration/management.

The analysis of data was done by using the method of content thematic analysis [90].

Lastly, we took into account the ethics and the code of conduct as for the ensuring of the participants' anonymity, providing information regarding the aims of the research, the right of voluntary participation, and ensuring discretion [87].

1 As validity we accept what Lincoln (2001) describes as internal validity. 2 In High School study students aged between 13-15 years old and attendance is mandatory. In Lyceum study students aged between 16-18 years old and attendance is not mandatory.

3 For instance, if the first school was in the Central Zone and it was a junior high school with a male principal, and if the next number referred again to a junior high school with a male principal, we did not select it and moved on to the next number 


\section{Results}

The object of investigation in the present study was the way in which the Attica Prefecture secondary school principals perceive the notion organizational or school culture, at a theoretical and practical level, in relation to the development of the school and the school climate, and finally expressed as vision. So, the questions addressed to the principals pertained to the perception of the notion or organizational/school culture, its contribution to the development of the school, its differentiation from the school climate, and their vision regarding the culture of their school unit.

Initially we asked the principals the first word that sprang in their mind when they hear the notion of organizational or school culture. The notion was perceived as calmness in the school environment and as a necessary prerequisite for the fulfillment of the educators' task (I.4), as contradicting and ineffective laws (I.8), as activities which regard organization and defined by the principal's vision (I.6), as rules or way of function of the school unit (I. 5,3 ), as common principle, views, ideas (I.5), as the school community members' behavioral way (I.7), as love toward the student (I.9), as theater (I.10). Also, the necessity for specialization was noted which, though, is related to school activity or computerization (I.2), as well as the incapacity of its approach (I.1).

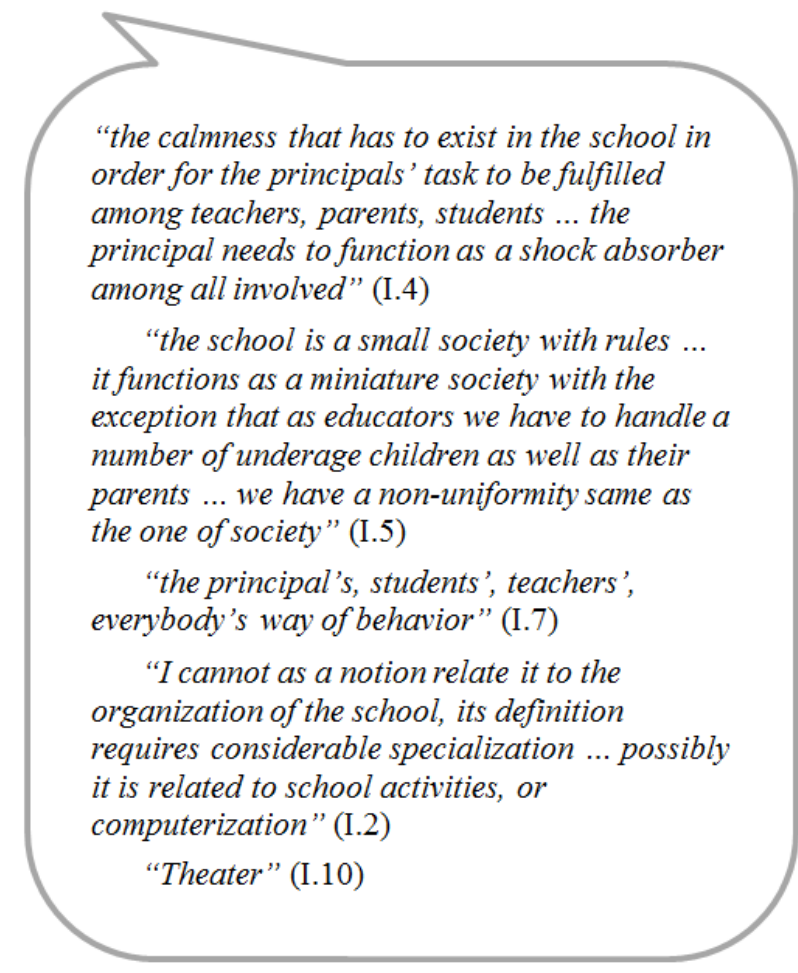

The next question concerned the contribution of culture to the development of the school, through examples. Initially non-existence of contribution was mentioned (I.2), mitigation of the positive contribution of culture by factors such as the principal's and teachers' personality or the pedagogical deficiency which characterizes a large portion of them (I.4), but also the limitation of contribution to the development of a special cultures among students who take part in cultural school activities (I.6), to the establishing of goals of the school organism as well as of their achievement (I.3), with the primary goal the formation of students as complete personalities (I. 7, 9, 5), to the energizing of all involved in the school unit towards the pragmatic and not typical application of laws about education (I.8). Lastly, as school culture is influenced by the distinct culture of the local community, the collaboration of the school unit with the local authorities towards the achieving of its goals is considered absolutely necessary (I.5).

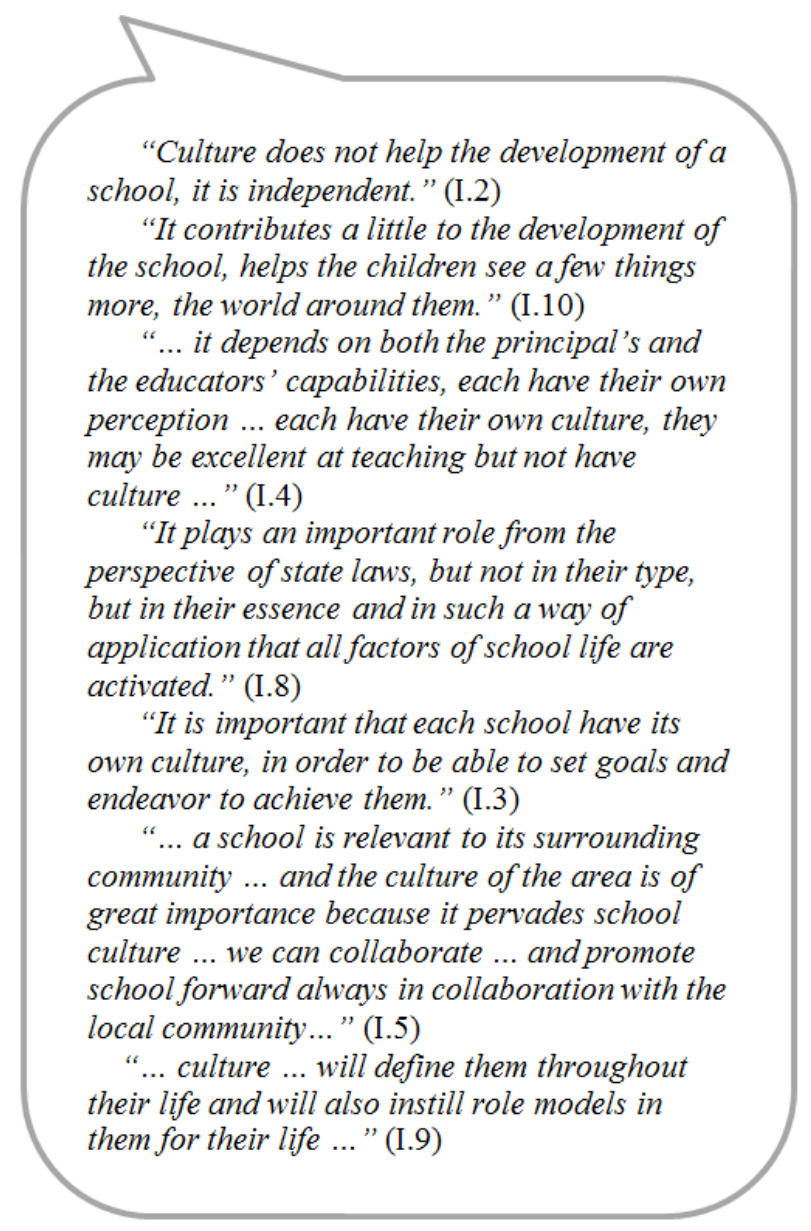

The interviewees, subsequently, were asked if culture is different from school climate and in what. Initially it was found out that both terms (2) were considered the same either vaguely (I.1) or due to their common definition as the spirit, the idea, the atmosphere of the school (I.9). In a parallel manner, correlation of school culture and climate was noted (3). More specifically, culture was approached as a prerequisite for the formation of school climate (I.5), permanent and more in-depth (I.6), aiming towards the growth and organization of the school community as a whole, opposing the fluidity of school climate (I.6), which constitutes a superficial expression of school reality (I.3). 
Lastly, a tendency for differentiation between the two notions was observed (5), either indistinctly (I. 2, 10, 7), or due to the distinctiveness of the local community (I. 4, 8). More specifically, the culture of the local community on one hand defines the students' distinctive culture influencing their receptiveness to pedagogical stimuli, a fact that that disturbs the calmness and organization of the school mainly when we refer to impoverished, both economically and culturally, areas (I.4) and on the other it is reflected on the school climate (I.8). Thus, the school culture should be made to adapt to school climate taking into account local area factors, in order for positive influence to be achieved (I.8).

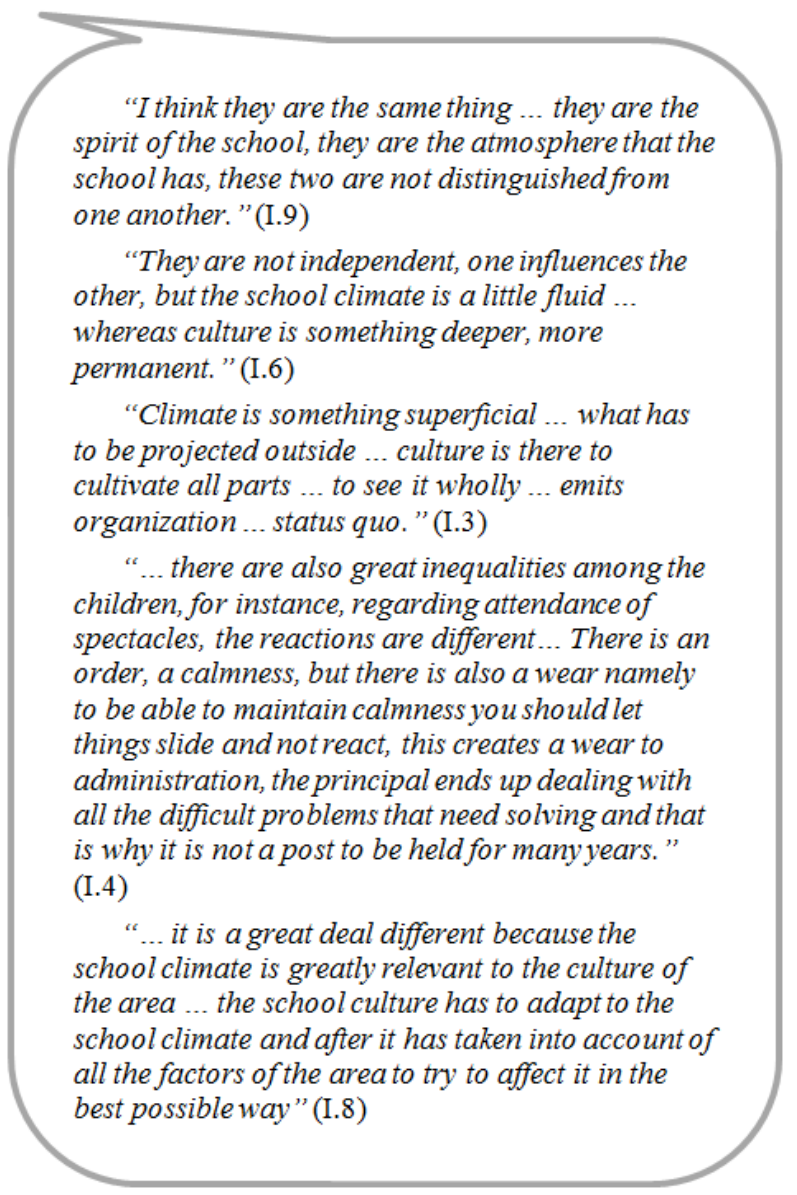

The last question that the principals were asked was how they visualize the culture of their school. The observation that bureaucracy and centralization of the educational system deter vision, do not leave space for initiative, and push towards the faithful following of the detailed curriculum was universal. Therefore, vision is expressed as the facilitation of individual pioneer acts by the educators (I. 1, 10), especially when the aim of our educational system has been transformed from the formation of healthy citizens to the making of higher education candidates, with an education deficiency though (I.8). By extension, the principals' vision was identified with free creative action (I.6), good school climate, collaborative disposition, but also the necessary contribution of all stakeholders to the school affairs (I. 2,4). It was identified with the pleasant school environment, an environment which projects happiness, respect, sense of justice, successes, with the aim of forming healthy citizens (I. 3, 5, 7, 9). Lastly, the decentralized system, the autonomous and flexible school, accountability, assignment of substantial responsibilities to the principal, like the responsibility of the appointment and development of teachers comprise a more groundbreaking facet of vision (I.8).

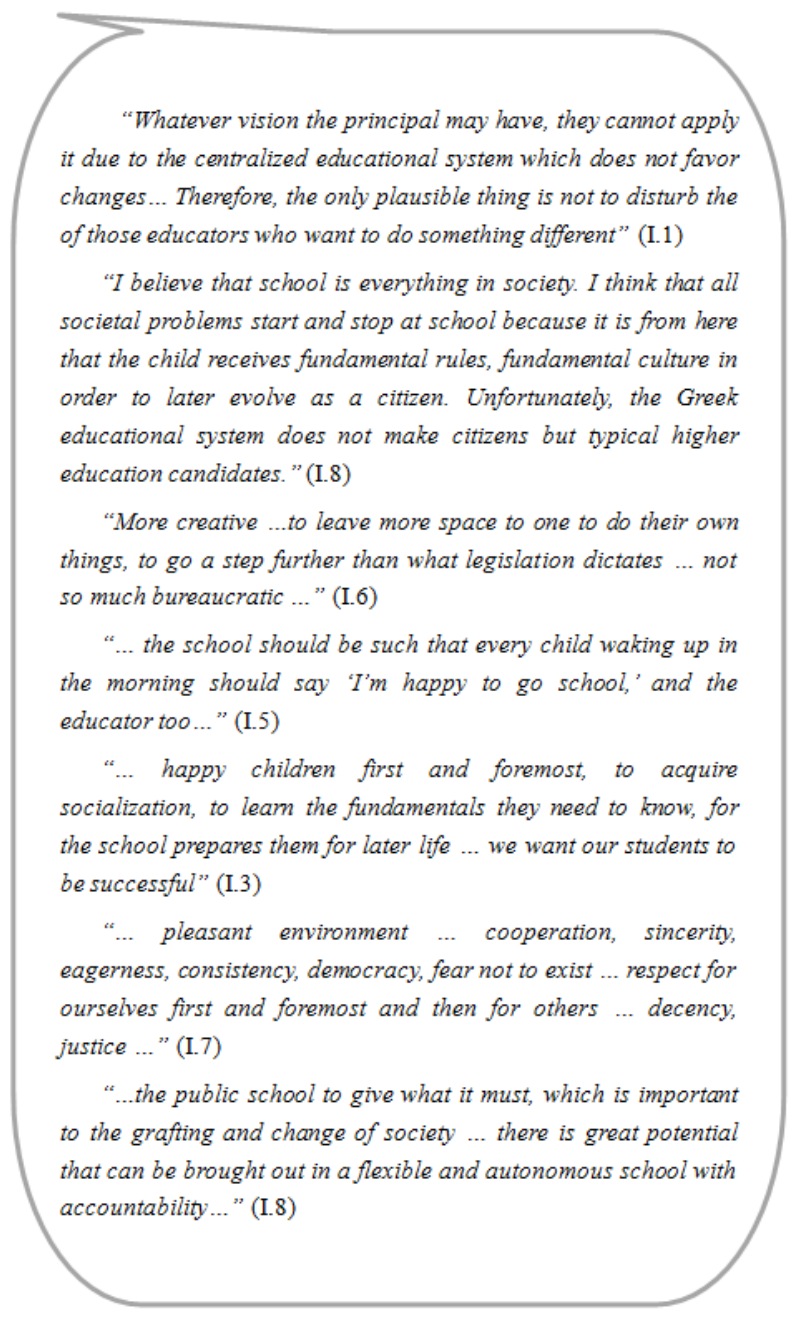

\section{Discussion}

The research question explored was how managers perceived the concept of school culture. The aim was to find out their perceptions of the concept of culture, its contribution to the development of the school, its differences from the school climate, and their vision for the school unit which they preside.

Our study adds to the pre-existing research on the delimitation of the notion of culture, especially regarding Schein's holistic approach, as well as its contribution to the development of the school. It confirms the findings of other 
surveys on the confusion of the terms culture and climate. Mostly, however, it differs from other surveys as it highlights the difficulty of a meaningful approach to culture, its depiction of a vision that is confounded with the mission of the school and its inability to be consciously linked to school efficiency, learning outcomes or job satisfaction.

More specifically, Attica Prefecture secondary school principals perceive the notion of organizational/school culture as calmness in the school environment (I.4), "a positive atmosphere" according to Turan \& Bektas [43], as laws (I.8), rules or way of how the school community functions (I. 5, 3), as activities relevant to organization and the principal's vision (I.6) $[43,50]$, as common values, views, ideas (I.5) $[18,41]$ or the members' way of behavior (I.7) $[57,7,58]$, as love for the student (I.9) confirming that an efficient headmaster allows the school to manage its critical human resources more effectively [53], as theater (I. 10). They profess that culture contributes to the better organization of the school community (I.1) as the headmaster deals with the administrative operation of the school as an organization through bureaucratic procedures involving day-to-day routine and conductive administrative tasks, within the highly bureaucratic and hierarchical Greek educational system [1], to the setting of aims and the achievement of targets (I.3), regarding the values desired to take place at school (42], or focused on common goals and learning objectives [51], with the formation of healthy students as the most important one (I. $7,9,5)$, provided that members of the school community, including parents, students, and staff, have the expectation their psychosocial, developmental, and educational needs will be taken care of [47 - 49], but also to the development of students' theatrical culture (I.10), to the stakeholders' activation toward the substantial application of educational laws (I.8) as it constitutes a challenge if headmasters, in centralized educational systems, may accept skeptically the central educational policy and shape along with all members of the school unit, its "internal" policy [2 - 4], to the increase of the members' interest for participation in school activities (I. 6). They also claim non-existence of contribution (I. 2) or its limitation due to the teachers' pedagogical deficiencies (I. 4).

Furthermore, the principals identify culture with school climate (I. 1,9), they distinguish the two notions (I. 2, 4, 10, 7,8 ) or they correlate them (I. 5, 6, 3), confirming that school culture becomes confused with the terms school climate [11, 19] and school ethos [11]. Coming to a conclusion, within the frame of an asphyxiating centralized system, their vision is attributed as the facilitation of educators' individual pioneer actions (I. 1, 10), as free creative expression (I. 6), as good school climate with conformations of collaboration, even if it is forced (I. 2, 4), as pleasant school environment (I. 3, 5, 7, 9) or as a decentralized, autonomous, and flexible school (I. 8).

Regarding the definition of culture, different ways for the perception of the notion are established indicating that even though evidence and studies suggest culture is a critical aspect of schools, and a crucial component for creating change in schools, there is no standard definition of culture [5,7-12] including the inability to interpret it (2) or the erroneous approach to it (1), as it was generally perceived as theater culture. More specifically, culture is attributed as rules or way of function (3) is confused with the Administration and Organization of the School Unit as a typical organization. Furthermore, it is identified with climate (1) confirming Gomez-Mejia et al. [61], who consider the inner climate of the organism one of the characteristics of organizational culture. Primarily, the researchers' holistic approach was not confirmed (3), like Schein's [29, 79], as each interviewee approached a different level of the notion. In more detail, the interpretation of culture as member' behavioral norms (1) pertains to the Schein's first level, confirming scholars and researchers mentioned in the present paper $[77,55,92,10$, $9380,1856,59,60,15]$. The approach as common values, ideas, perceptions (1) pertains to Schein's second level [26, $55,92-9310,7659,60,15]$, while as human emotions love for the child pertains to Schein's third level [10, 93-94].

As for the issue of the contribution of culture to the development of the school, identification of organizational culture with the Administration and Organization of the School Unit is inferred (5), as its contribution to organization (1), to the setting of aims (1), and to the formation of healthy students (3), pertain more to the educational organism as a typical organization [95]. Clearly the contribution of culture to better organization and targeting confirm research data [62-64], without, however, in our research, culture being perceived as the most significant factor for the restructuring of the school [95-96].

Additionally, by the activation of all stakeholders toward the substantial and not typical application of education laws (1) an organism is established, on one hand, focused on what is truly important and valuable [98-99], and, on the other, consisted of members dedicated to the group endeavor having the appropriate behavior [81], confirming the relationship between school culture and organizational commitment [69, 73-74]. In parallel, culture contributes to initiatives for the betterment of the school [100], as long as the members show an increasing interest in participating in school activities (1), confirming that culture enhances the energy, motivation and vitality of school community members [75], while also decreasing the cases of members leaving the organism [82], as is evident by the members' intention to stay at the specific school (1) in order to carry out the activities.

On the contrary, the absence of the contribution of culture to the development of the school is not confirmed by scholars/researchers, while its contribution to the students' who participate take part in the cultural activities 
of the school specific culture is considered erroneous, as the notion is perceived as theater culture (1). Lastly, the mention of factors that limit its positive contribution (personality, pedagogical deficiency) (1), shows the mutually-depending relationship of culture with the members of the organism [35].

Regarding the difference between culture and school climate, on one hand an accepted interpretation of climate was defined as (1) the atmosphere of the school organism $[34,22,35]$, on the other the prevailing confusion of the two notions was generally validated [11, 19]. More specifically, the differentiation between the two notions claimed by the majority of the interviewees (5) either was not justified (3) or was erroneously substantiated (2), as school culture was identified with the culture of the local community, which contributes to the formation of the students' specific culture influencing, by extension, school climate. In addition to the correlation of the notions (3) the permanence of culture (3) is confirmed [38, 40] opposing the fluidity, the temporary character of climate $[38,27]$. The total identification (2) of one notion with the other primarily confirms the confusion of organizational culture with climate according to Schein [21, 20,27] and on a second level confirms the scholars who perceive the two notions identical because, according to Mintzberg [14], the culture of a school is reflected on the school climate.

As for their (the principals') vision regarding their school culture, factors were recorded (bureaucracy, centralization) which oppose the notion of vision (10), but also the spirit of education (1). By extension, the principals' vision is reduced to noting the negative sides in the function of an organism without, though, including the meaning of culture. In more detail, vision is involved in the school mission, seeking to form healthy citizens in a pleasant environment (4) or expressed as collaborative disposition, even forced (2), as facilitation of individual pioneer actions by educators (2), as free creative expression (1). Although the pleasant environment, cooperation, innovative action and creativity confirm the linking of culture to job satisfaction [73-74], in this case some sides of the Greek educational reality are erased, such as the absence of collective culture, the prevalence of individualism, and the compelling need of undertaking initiatives.

In conclusion the lack of vision confirms Bagakis's [101] point that "the [Greek] schools usually do not have targets to meet and they do not have substantial pedagogical discussions. It is often evident that the 'letter of the law' is [the main] schools' ... priority ... The culture of the 'automatic pilot' and the lack of vision and orientation of each school is evident in the Greek context". Lastly, the groundbreaking identification of vision with the decentralized system, with the autonomy and flexibility of the school, with the assignment of substantial roles and initiatives constitutes an expression of culture (1), erasing, in fact, elements of culture of effective organisms $[102,18]$ and highlighting that the headmaster of the school unit, who functions as a bearer of changes, innovations, and visions, surpassing the bureaucratic dimension of his role, is one of the most important factors of their success [103-105].

\section{Conclusions}

The present study concerned the investigation of Attica Prefecture secondary school principals' perceptions on the issue of organizational culture. The notion is complex, multi-leveled, a tool for restructure, improvement, change, it reveals a philosophy for the administration of the education organism, demanding as base the holistic approach of the education process, the strategic orientation, the development of a system and direction of values, as leadership and organizational culture are in a constant process of interaction and heteronomy.

By analyzing the data, difficulty in defining organizational culture, incapacity to holistically perceive the notion, and confusion with the Administration and Organization of the School unit. Culture was not perceived as a touchstone for the betterment and restructuring of the education organism, but as supporting factor for the function of a typical organization. In logical turn, confusion of the notions culture and climate was observed, as well as restraining of vision within an asphyxiating education process, detached from the spirit of culture. It was obviously expected not for the educators' incapacity to become evident, but the incapacity of our education system, as the responsibility is attributed to a deficiency of education policy. So the justified question arises as to how the totally reasonable demand of the modern education reality for the shaping, handling, and change of culture will be materialized? How will the transition from bureaucratic process towards creative education process take place? What is demanded, in order to go from theory to action?

Future research should focus on depth on headmasters' stereotyped perceptions about the notion of culture, its significance and their resistance in change.

\section{Limitations}

When generalizing the results of this study, the limited sample should be taken into account. Nevertheless, the data don't lose their value.

\section{Acknowledgements}

We are grateful to George Gkritzios for the translation and the revision of the paper. Also, we are grateful to principals for their contribution in the research. 


\section{REFERENCES}

[1] Pashiardis, P. (2001). Secondary principals in Cyprus: the views of the principal versus the views of the teachers-a case study. International Studies in Educational Administration, 29 (3), 11-27.

[2] Sergiovanni, T.J. (1991). The Principalship: A Reflective Practice Perspective. Needham Heigths, Mass: Allyn and Bacon.

[3] Leech, D. \& Fulton, C. R. (2008). Faculty perceptions of shared decision making and the principal's leadership behaviours in secondary schools in a large urban district. Education, 128 (4), 630-644.

[4] Williams, H. S. (2009). Leadership capacity-a key to sustaining lasting improvement. Education, 130 (1), 30-41.

[5] Bolman, L. G., \& Deal, T. E. (2008). Reframing Organizations: Artistry, Choice, and Leadership ( $4^{\text {th }}$ ed.). San Francisco, California, United States: Jossey-Bass.

[6] Chhokar, J. S., Brodbeck, F. C., and House, R. J. (Eds.). (2008). Culture and Leadership Across the World: The GLOBE Book of In-Depth Studies of 25 Societies. Mahwah, New Jersey, United States: Lawrence Erlbaum Associates.

[7] Hofstede, G., \& Hofstede, G. J. (2005). Cultures and Organizations: Software of the Mind, Intercultural Cooperation and Its Importance for Survival. New York, New York, United States: McGraw-Hill.

[8] Hofstede, G. (2001). Culture's Consequences: Comparing Values, Behaviors, Institutions, and Organizations Across Nations. Thousand Oaks: SAGE Publications.

[9] House, R. J., \& Javidan, M. (2004). Overview of GLOBE. In R. J. House, P. J. Hanges, M. Javidan, P. W. Dorfman, and V. Gupta, (Eds.) Culture, Leadership, and Organizations: The GLOBE study of 62 Societies (pp. 9-28). Thousand Oaks: Sage Publications.

[10] Schein, E.H. (2004). Organizational Culture and Leadership (3rd ed.). San Francisco: Jossey-Bass.

[11] Peterson, K. D., \& Deal, T. E. (2009). Shaping School Culture (2nd ed.). San Francisco, California, United States: Jossey-Bass.

[12] Sarason, S. B. (1996). Revisiting the Culture of the School and the Problem of Change. New York: Teachers College Press.

[13] Ouchi, W. G. (1981). Theory Z: How American Business Can Meet the Japanese Challenge. Reading, Mass: Addison - Wesley.

[14] Mintzberg, H. (1979). The structuring of organizations: A synthesis of the research. Englewood Cliffs, N.J: Prentice-Hall.

[15] Pashiardis, G. (2014). Educational Leadership. From period of favorable indifference to contemporary era. Athens: Metaixmio (in Greek).

[16] Hargreaves, A. (1994). Changing teachers changing times. London: Cassell.

[17] Hargreaves, D. (1995). «School culture, school effectiveness and school improvement». School Effectiveness and School
Improvement, 6 (1), 23-46.

[18] Hoy, W. K., \& Miskel, C. G. (2008). Educational Administration. Theory, Research, and Practice. New York: McCraw-Hill.

[19] Miron, B. J. (2014). School principal influence actions, climate, culture and school performance. Doctoral dissertation. Florida Atlantic University. Retrieved 24.04.2018. Available at http://fau.digital.flvc.org/islandora /object/fau\%3A30796

[20] Schneider, B., Ehrhart, M G., \& Macey, WH. (2011). Perspectives on organizational climate and culture. In S. Zedeck (Ed), APA Handbook of Industrial and Organizational Psychology: Vol. 1. Building and Developing the Organization, (pp. 373-414). Washington, DC: Am. Psychol. Assoc.

[21] Schein, E.H. (2000). Sense and nonsense about culture and climate. In N. M. Ashkanasy, C. P. M. Wilderom, \& M. F. Peterson (Eds.), Handbook of organizational culture and climate (pp. xxiii-xxx). Thousand Oaks, CA: Sage Publications, Inc.

[22] Ostroff, C., Kinicki, A.J., \& Tamkins, M.M. (2003). Organizational culture and climate. In W.C. Borman, D.R. Ilgen \& R.J. Klimoski (Eds.), Handbook of psychology: Industrial and organizational psychology. 12, 565-594. Hoboken, NJ: John Wiley \& Sons.

[23] Koutouzis, M. (1999). General Principles of Management, Tourism legislation and Organization of Employees and Collective Organizations. Patras: Greek Open University (in Greek).

[24] Campo, C. (1993). Collaborative School cultures: How principals make a difference. School Organization, 13 (2), 119-125.

[25] Pashiardis, G. (2000). School climate in elementary and secondary schools: Views of Cypriot principals and teachers. International Journal of Educational Management, 14(5), 224-237.

[26] Mintzberg, H. (1989). Mintzberg on Management: inside our strange world of organizations. New York: Free Press.

[27] Ekvall, G., \& Ryhammer, L. (1999). The creative climate: Its determinants and effects at a Swedish university. Creativity Research Journal, 12 (4), 303-310.

[28] Mylona, Z. D. (2005). Principal and Effective SchoolPrincipals' and Teachers' Opinions and Attitudes. Thessaloniki: Kyriakidis $\mathrm{Br}$ (in Greek).

[29] Schoen, L. T., \& Teddie, C. (2008). A new model of culture: A response to call for conceptual clarity. School Effectiveness and School Improvement, 19(2), 129-153. DOI: $10.1080 / 09243450802095278$

[30] Kowalski, T., \& Reitzug, U. (1993). Contemporary School Administration. New York: Longman.

[31] Van Houtte, M. (2004). Why Boys Achieve Less at School Than Girls: The Difference Between Boys' and Girls' Academic Culture. Educational Studies, 30 (2), 159-173.

[32] Kythreotis, A. (2006). Investigating Relations between Leadership Style, Culture and Effectiveness in Primary Schools of Cyprus. (Doctoral Dissertation, Department of 
Educational Sciences, University of Cyprus, in Greek)

[33] [33] Schneider, B. (2000). The psychological life of organizations. In N.M. Ashkanasy, C.P.M. Wilderom \& M.F. Peterson (Eds.). Handbook of organizational culture and climate (pp. xvii-xxi). California: Sage.

[34] Sergiovanni, T.J. \& Starratt R.J. (1998). Supervision: A Redefinition $\left(6^{\text {th }}\right.$ ed.). New York: McGraw-Hill.

[35] Chatzipanagiotou, P. (2008). The role of culture in effectiveness of school organization. Training Guide. In $Z$. Papanaoum, (Ed.), Intercultural Education and Education (pp. 213-230). Thessaloniki: Ministry of Education (in Greek).

[36] Jones, A.P., \& James, L.R. (1979). Psychological climate: Dimensions and relationships of individual and aggregated work environment perceptions. Organizational Behavior and Human Performance, 23, 201-250.

[37] Rentsch, J. R. (1990). Climate and culture: Interaction and qualitative differences in organizational meanings. Journal of Applied Psychology, 75, 668-681.

[38] Denison, D. R. (1996). What is the difference between organizational culture and organizational climate? A native's point of view on a decade of paradigm wars. The Academy of Management Review, 21, 619-654.

[39] Trice, H.M., \& Beyer, J.M. (1993). The Cultures of Work Organizations. Englewood Cliffs, NJ: Prentice-Hall.

[40] Schein E.H. (2010). Organizational Culture and Leadership ( $4^{\text {th }}$ ed.). San Francisco: Jossey-Bass.

[41] Demirtaş, Z. (2010). Okul kültürü ile öğrenci başarısı arasındaki ilişki [The relationship between school culture and student achievement]. Eğitim ve Bilim Dergisi, 35(158), 3-13.

[42] Dean, J. (1999). Improving the primary school. New York: Routledge.

[43] Turan, S., \& Bektas, F. (2013). The relationship between school culture and leadership practices. Egitim Arastirmalari-Eurasian Journal of Educational Research, 52, 155-168.

[44] Hatch, M. J. (2011). Organizations: A very short introduction. New York: Oxford University Press.

[45] Schein, E.H. (1985). Organizational Culture and Leadership. San Francisco: Jossey-Bass.

[46] Deal, T.E., \& Peterson, K.D. (1990). The Principal's Role in Shaping School Culture. Washington, D.C.: Office of Educational Research and Improvement.

[47] Colia, C. B. (2002). The relationship between culture and climate and school effectiveness. Doctoral Dissertation. University of Colorado. Retrieved 10.05.2018. Available at http://digital.auraria.edu/AA00001754

[48] Ewen, N. A. (2004). An Examination of the Culture of a School Board. Royal Roads University, Leadership and Training. Ontario: National Library of Canada.

[49] Kent, P. (2006). Finding the Missing Jigsaw Pieces: a new model for analyzing school culture. Management in
Education, 20(3), 24-30.

[50] Durukan, H. (2006). Okul yöneticisinin vizyoner liderlik rolü [The visioner role of school administrator]. Ahi Evran Üniversitesi Kırşehir Eğitim Fakültesi Dergisi (KEFAD) 7(2), 277-286.

[51] Leithwood, K., \& Riehl, C. (2003, April). What do we already know about successful school leadership? Paper presented at the American Educational Research Association Annual Conference, Chicago.

[52] Theofilidis, Ch. (2014). Self-evaluation of School: Schools are getting know their school. Athens: Grigoris (in Greek).

[53] Tschannen-Moran, M. (2004). Trust Matters: Leadership for Successful Schools. San Francisco, Calif, USA: Jossey-Bass.

[54] Pashiardis, G. (2008). School culture. Notion, Improvement and Change. Retrieved in 20.10.2017 Available at: http://www.pee.gr/wp-content/uploads/praktika_synedrion files/pr_syn/s_nay/c/2/georgia_pasiardi.htm (in Greek).

[55] Deshpande, R., \& Webster, F. E. (1989). Organizational Culture and Marketing: Defining the Research Agenda. Journal of Marketing, 53(1), 3-15.

[56] Bourantas, D. (2002). Managemet. Theoretical Background -Contemporary Practices. Athens: Benou (in Greek).

[57] Barth, R. S. (2002). The culture builder. Educational Leadership, 59, 6-11.

[58] Wheatley, M. J. (2006). Leadership and the New Science: Discovering Order in a Chaotic World. San Francisco, California, United States: Brett-Koehler Publishers Inc.

[59] Ravasi, D., \& Schultz, M. (2006). Responding to organizational identity threats: Exploring the role of organizational culture. Academy of management journal. 49(3), 433-458.

[60] Xiaoming, C., \& Junchen, X. (2012). A Literature Review on Organizational Culture and Corporate Performance. International Journal of Business Administration, 3(2), 29-37.

[61] [61] Gomez-Mejia, L., Balkin, D., \& Cardy, R. (2015).

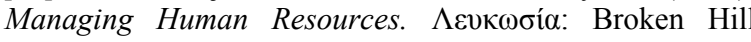
Publishers (in Greek).

[62] Westhuizen, P. C., Mosoge, M. J., Swanepoel, L. H., \& Coetsee, L. D. (2005). Organizational culture and academic achievement in secondary schools. Education and Urban Society, 38, 89-109.

[63] Ojo, O. (2009). Impact assessment of corporate culture on employee job performance. Business Intelligence Journal, 2 (2), 388-397.

[64] Gomez, M. O., Marcoulides, G. A., \& Heck, R. H. (2012). Examining culture and performance at different middle school level structures. International Journal of Educational Management, $26 \quad$ (2), 205-222, https://doi.org/10.1108/09513541211202004.

[65] Cavanagh, R.F., \& Waugh, R.F. (2004). Secondary school renewal: the effect of classroom learning culture on educational outcomes. Learning Environments Research, 7 (3), 245- 269. 
[66] [66] Gruenert, S. (2005). Correlations of collaborative school cultures with student achievement. NASSP Bulletin, 89 (645), 43-55.

[67] Kowalski, T. J., \& Hermann, K. (2008). Evaluating the culture of high schools in relation to their demographic characteristics and performance. In W.K. Hoy \& M.F. DiPaola (2008). (Eds.). Improving schools: studies in leadership and culture (pp. 55-71). Charlotte, NC: Information Age Publishing.

[68] Şahin, S. (2011). The relationship between instructional leadership style and school culture (Izmir Case). Educational Sciences: Theory \& Practice, 11 (3), 1920-1927.

[69] Karadağ, E., Kılıçoğlu, G., \& Yılmaz, D. (2014). Organizational cynicism, school culture, and academic achievement: The study of structural equation modeling. Educational Sciences: Theory \& Practice, 14 (1), 102-113.

[70] Hallinger, P. (2010). Developing instructional leadership. Studies in educational leadership, 11, 61-67, DOI: 10.1007/978-90-481-9106-2 5

[71] Leithwood, K., Harris, A., \& Hopkins, D. (2008). Seven Strong Claims about Successful School Leadership. School Leadership and Management, 28 (1), 27-42. DOI: $10.1080 / 13632430701800060$

[72] Wallace, M. (2002). Modelling Distributed Leadership and Management Effectiveness: Primary School Senior Management Teams in England and Wales. School Effectiveness and School Improvement, 13 (2), 163-186.

[73] Lok, P., \& Crowford, J. (1999). The relationship between commitment and organizational culture, subculture, leadership style and job satisfaction in organizational change and development. Leadership and Organization Development, 20 (7), 365-374, https://doi.org/10.1108/014 37739910302524.

[74] Hatchett, D. (2010). The impact of school culture, teacher job satisfaction and student attendance rates on academic achievement of middle school students. Unpublished doctoral dissertation, University of Louisville.

[75] Verbeke, W., Volgering, M., \& Hessels, M. (1998). Exploring the conceptual expansion within the field of organizational behaviour: Organizational climate and organizational culture. Journal of Management Studies, $35(3), 303-330$.

[76] [76] Glisson, C., \& James, L.R. (2002). The cross-level effects of culture and climate in human service teams. Journal of Organizational Behavior, 23, 767-794.

[77] Smircich, L. (1983). Concepts of culture and organizational analysis. Administrative Science Quarterly, 28, 339-358. DOI: $10.2307 / 2392246$.

[78] Detert, J., Schroeder, R. \& Mauriel, J. (2000). A Framework for Linking Culture and Improvement Initiatives in Organisations. The Academy of Management Review, 25(4), 850-863.

[79] Van Houtte, M., \& Maele, D. (2011). The black box revelation: in search of conceptual clarity regarding climate et culture in school effectiveness research. Oxford Rewiew of Education, 37(4), 506-510.
[80] Hoy, W., \& Miskel, C. (2001). Educational Administration: Theory Research and Practice (6 ${ }^{\text {th }}$ ed.). New York: McGraw-Hill, Inc.

[81] [81] Robbins, S.P. (1991). Organizational Behavior: Concepts, Controversies, and Applications ( $5^{\text {th }}$ ed.). Englewood Cliffs, NJ: Prentice-Hall.

[82] Mowday, R., Porter, L., \& Steers, R. (1982). Organizational linkages: The psychology of commitment, absenteeism, and turnover. New York: Academic Press.

[83] Denison, D. R. (1990). Corporate Culture and Organizational Effectiveness. New York: Wiley.

[84] Iosifidis, Th. \& Spyridakis, M. (Eds). (2006). Qualitative Social Research: methodological approaches and data analysis. Athens: Kritiki (in Greek).

[85] Berg, B.L. (2001). Qualitative research methods for the social sciences $\left(4^{\text {th }} \mathrm{ed}\right.$.). Boston: Allyn and Bacon.

[86] Rubin, H.J., \& Rubin, I. S. (2005). Qualitative interviewing. The art of hearing data ( $2^{\text {nd }} \mathrm{ed}$.). Thousand Oaks, CA: Sage.

[87] Cohen, L., Manion, L., \& Morrison, K. (2008). Methodology of Educational Research. (transl. S. Kyrianakis, M. Mavraki, Ch. Mitsopoulou, P. Mpithara, \& M. Filopoulou). Athens: Metaixmio (in Greek).

[88] Kendall, M. G. \& Smith, B.B. (1938). Randomness and random Sampling Numbers. Journal of Statistixal Society, 101, 164-166.

[89] Polit, D., and Hungler, B. (1999). Nursing Research: Principle and Method ( $6^{\text {th }}$ ed.). Philadelphia, Lippincott Company.

[90] Braun, V., \& Clarke, V. (2006). Using Thematic Analysis in Psychology. Qualitative Research in Psychology, 3(2), $77-101$

[91] Symeou, L. (2007). Validity and reliability in qualitative educational research. In D. Chatzidimou (Ed). Proceedings of the 5ht Greek Conference of Greek Pedagogical Society, Vol. 2, (pp. 333-339). Thessaloniki: Kyriakidis (in Greek).

[92] Hargreaves, D. H., \& Hopkins, D. (1991). The Empowered School: The Management and Practice of Development Planning. London: Cassell.

[93] Schein, E.H. (1992). Organizational culture and leadership $\left(2^{\text {nd }}\right.$ ed.). San Francisco: Jossey-Bass.

[94] Anthopoulou, S.S. (1999). Human Resources Management. In A. Athanasoula - Reppa, S.S. Anthopoulou, S. Katsoulakis, G. Mayrogiorgos (Ed.), Management of Educational Units, Vol. II (pp. 17-92). Patras: Greek Open University (in Greek). [95] Chatzipanagiotou, P. (2011). School Administration and teachers' partnership in decision-making progress. (Doctoral dissertation). Thessaloniki: Aristotle University (in Greek).

[95] Leithwood, K., Jantzi, D., \& Fernandez, A. (1994). Transformational leadership and teachers' commitment to change. In J. Murphy \& K. S. Louis (Eds.). Reshaping the principalship (pp. 77-98). Thousand Oaks, CA: Corwin.

[96] Nicolaidou, M., \& Ainscow, M. (2002). Understanding 'failing' schools: the role of culture and leadership. Paper 
presented at the British Education Research Association Annual Conference, University of Exeter. Retrieved 12-14 September 2002 from http://www.leeds.ac.uk/educol/docu ments/00002522.htm

[97] Deal, T.E., \& Peterson, K.D. (1999). Shaping school culture: The heart of leadership. San Francisco: Jossey-Bass.

[98] Christofidou, E. (2011). Culture and Climate. Retrieved in 11.04.2017 fromhttp://www.moec.gov.cy/dde/anaptyxi_vel tiosi_scholeiou/tomeis_drasis/klima_koultoura/parousiaseis /koultoura_kai_klima.pdf (in Greek).

[99] Leithwood, K., Jantzi, D., Coffin, G., \& Wilson, P. (1996). Preparing school leaders: What works? Journal of School Leadership, 6(3), 316-342.

[100] Bagakis, G. (2007) "Schools" support within the Carpe Vitam programme. Leadership for Learning: 2nd Low secondary school of Petroupolis'. In G. Bagakis, K.
Demertzi and T. Stamatis (eds), A School Learns: Development and School Self-evaluation within the Carpe Vitam: Leadership for Learning Project (pp. 151-165). Athens Greece: Livanis Publications (in Greek).

[101] Saphier, J., \& King, M. (1985). Good seeds grow in strong cultures. Educational Leadership, 42(6), 67-74.

[102] Brewer, J. \& Blasé, J. (2001). Ten steps to success. Journal of Staff Development, 22 (1), 30-31.

[103] Everard, K. B., Morris, G. \& Wilson, I. (2004). Effective School Management $\left(4^{\text {th }}\right.$ ed.). London: Paul Chapman.

[104] Wiliamson, R. \& Blacburn, B. R. (2009). Personal and shared vision: a commitment to increased rigor. Principal Leadership, 10(3), 56-59. 